\title{
Stand-scale reconstruction of late Holocene forest succession on the Gdańsk Upland (N. Poland) based on integrated palynological and macrofossil data from paired sites
}

\author{
Anna Pędziszewska ${ }^{1} \cdot$ Małgorzata Latałowa $^{1}$
}

Received: 8 January 2015/Accepted: 31 August 2015/Published online: 17 October 2015

(C) The Author(s) 2015. This article is published with open access at Springerlink.com

\begin{abstract}
This study concerns the stand-scale palaeoecological reconstruction of the subsequent stages of late Holocene vegetation development on habitats recently covered by beech-dominated woodland in the southern Baltic region. The data, based on pollen, non-pollen palynomorphs, macrofossil and charcoal analyses from two close-lying sites, demonstrated that each of the subsequent late Holocene shifts in dominating forest communities took place because of human impact coupled with climatic events or episodic human-made disturbances. Shifts from the Tilia dominated forest to the Quercus-Corylus plant community at around $3300 \mathrm{BC}$ was most probably driven by the coupled effect of climate change and human activity. Human impact was the primary driver of the final Corylus decline and concurrent major Carpinus expansion at c. 460 BC, and the Carpinus decline followed by Fagus expansion at c. AD 900. Carpinus had been lingering on the edge of a major expansion in the local forest for at least 2,500 years while Fagus had persisted in a small admixture for no fewer than 1,500 years before becoming important forest constituents. Our data illustrate the role of episodic disturbances as turning points that initiate long-term vegetation changes.
\end{abstract}

Communicated by: K.-E. Behre.

Electronic supplementary material The online version of this article (doi:10.1007/s00334-015-0546-7) contains supplementary material, which is available to authorized users.

Małgorzata Latałowa

malgorzata.latalowa@biol.ug.edu.pl

1 Laboratory of Palaeoecology and Archaeobotany, Department of Plant Ecology, University of Gdańsk, Wita Stwosza 59, 80-308 Gdańsk, Poland
Keywords Tilia decline $\cdot$ Fagus expansion - Coppice wood · Long-term forest dynamics · Mire palaeohydrology · Late Holocene climate changes

\section{Introduction}

One of the major challenges in understanding past ecosystem dynamics is to distinguish climatic from anthropogenic impacts as driving factors in vegetation changes. This question has been fundamental since early developments in pollen analysis and until recently has been a target in the search for methods enabling better assessment of the role of both factors (e.g. Lieschke et al. 2002; Bradshaw 2008). However, problems arise from more than the objective difficulty in separating the ecological effects of both factors (but see Reitalau et al. 2013). We should also assume that a great part of the Holocene vegetation changes resulted from the combined interaction and cumulative effect of climate dynamics and human activity. There have been numerous potential combinations for such interactions in which climate or humans initiated or reinforced the ecological process, but the final effect was a result of both factors. The history of Tilia decline and Fagus expansion in large European areas may serve as a good example in this respect (summarized by Bradshaw and Sykes 2014).

Understanding processes underlying changes in the past, present and future forest ecosystems requires following the history of particular forest-forming tree taxa in different parts of their geographic distribution range. Their inherent migration abilities, fitness in different climates, light and soil conditions, and resistance against pests, fire, animal grazing and different forms of human activities are all important in inter-species competition for establishment, expansion and 
dominance or just dynamic co-existence with other tree taxa. Thus, in different areas, specific forest composition results in specific species' mutual competitiveness, which is crucial for tree taxa population dynamics and consequently the dynamics of the whole ecosystem. It implies that knowledge of the long-term, more discrete processes at the ecosystem level is not only a necessary condition for better understanding past vegetation interactions with a range of environmental factors but also for comprehensive competence in assessing the present vegetation changes and modelling future trends (Bradshaw and Sykes 2014).

The particularly detailed data on the palaeoecology of the European temperate forests concern southern Scandinavia because of the region's long tradition of stand-scale pollen analysis (Iversen 1964, 1969; Andersen 1984; Björkman 1997; Bradshaw and Lindbladh 2005; Lindbladh and Foster 2010). The limited source area of pollen, typical of this kind of study, enables palaeoecological reconstruction related to patches of vegetation in the immediate vicinity of a pollen site, thus affording data on the history of a real plant community (summarized by Bradshaw 2007).

In this study, we follow the stand-scale type of research with the aim of reconstructing the subsequent stages of late Holocene vegetation development on the habitats recently covered by beech-dominated woodland in the southern Baltic region. For our study, we selected an area for which continuity of the woodland has been documented by all the available historical maps, which allowed us to infer that in a more ancient past this area also retained its forest cover. We have also assumed that a combination of the data based on pollen, non-pollen palynomorphs (NPPs), macrofossils and charcoal from paired sites should shed more light on the potential causal links among forest succession, human impact and hydroclimatic conditions. The main questions addressed in this research concern chronology of vegetation changes and identification of the agents responsible for the vegetation shifts.

\section{Study area}

The Gdańsk Upland is the most eastern part of the Kashubian Lake District in northern Poland (Fig. 1). To the east, it borders on the low platform of the coastal zone of the Gulf of Gdańsk (the southern Baltic Sea). The morphology of this terrain has been shaped by the Vistulian (Weichselian) ice sheet and represents a typical postglacial landscape. The area neighbouring our palaeoecological sites is mostly made up of strongly undulated ground moraine reaching over $100 \mathrm{~m}$ a.s.l. Its marginal zone slopes towards the coastal platform. This area is strongly diversified, being dissected by a dense network of steep and branched dry gullies and depressions, some of them filled with small

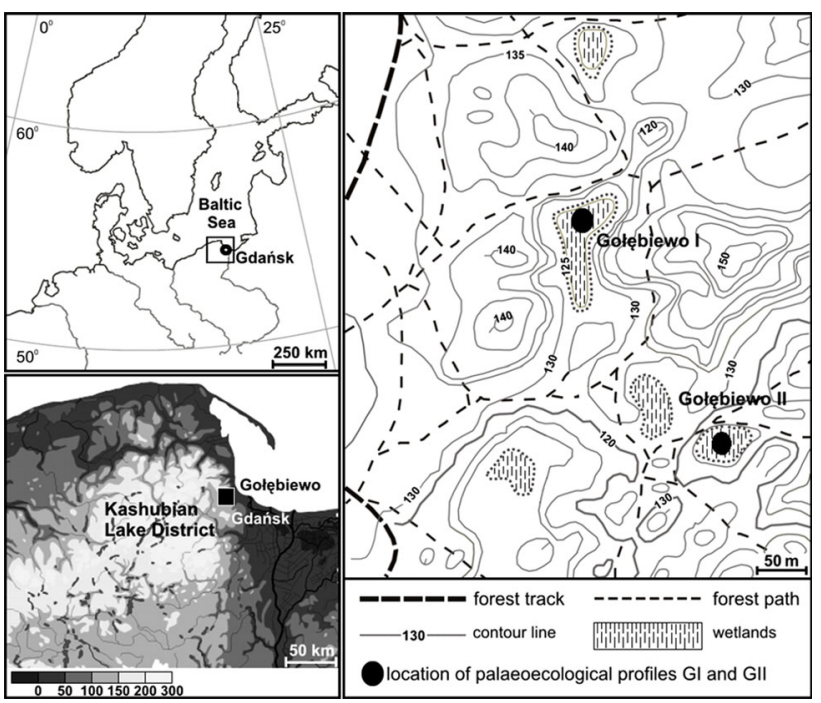

Fig. 1 Geographic location of the study area and position of the two analysed sites

mires. Local differences in relief can be up to $80 \mathrm{~m}$ with a slope gradient of $40^{\circ}$. The most common substrates for soil cover are clay or sandy-clay morainic formations; however, patches of more sandy soils also occur, and hydrogenic soils cover the bottoms of low-lying valleys.

The climate of the study area is typically temperate, under the influence of Atlantic air masses, with relatively high air humidity $(79 \%)$ and an average annual temperature of $7.2{ }^{\circ} \mathrm{C}$. The coldest month is January, with an average temperature of $-1.5^{\circ} \mathrm{C}$. July is the hottest month with an average temperature of $17{ }^{\circ} \mathrm{C}$. The annual precipitation is rather moderate (c. $590 \mathrm{~mm}$ ). Relatively frequent and strong winds, mostly westerly, are typical for this area (Owczarek et al. 2007).

The Gdańsk Upland is covered by extensive woodland of ca. 20,000 ha that is partly protected as the Tri-City Landscape Park. Beech forests and mixed deciduous or coniferous forests with a large proportion of beech are the most characteristic for this area. Acid beech forest (Luzulo pilosaeFagetum) and, to a lesser extent, oak-beech forest (FagoQuercetum) cover the highest parts of the slopes. Patches of fertile beech forest (Melico-Fagetum) occur in the intermediate locations while stands of oak-hornbeam forests (Stellario-Carpinetum) with an admixture of beech and pine occupy the lower parts of the slopes. Mixed oak-pine forest (Pino-Quercetum) is of little spatial importance in this area. In the valleys, along streams, riverine forests with Alnus glutinosa, Ulmus laevis and Fraxinus excelsior occur. Although this forest complex borders immediately on a large, old urban agglomeration, it has retained a high degree of naturalness (Herbich 2000) and a high proportion (above $27 \%$ ) of trees older than 100 years. Only small fragments of the area outside the forest are occupied by meadows or fields. 


\section{Study sites}

Gołębiewo I (G/I) and Gołębiewo II (G/II) are small, insideforest mires located on the east-facing edge of the Gdańsk Upland $\left(54^{\circ} 27^{\prime} \mathrm{N} ; 18^{\circ} 30^{\prime} \mathrm{E}\right)$ (Fig. 1). They are situated about $200 \mathrm{~m}$ from one another, between small hills covered by patches of sandy-clay soil. Their neighbourhood is overgrown by both acid and fertile beech forests and mixed acidophilous oak-beech forest. Frequent old stands of pine and spruce are mostly remnants of earlier plantations.

The G/I site fills an elongated depression, c. 0.6 ha $(150 \times 40 \mathrm{~m})$ in surface area, surrounded by rather steep slopes covered by beech forest. It is a peat bog of transitional character including elements of minerogenic and

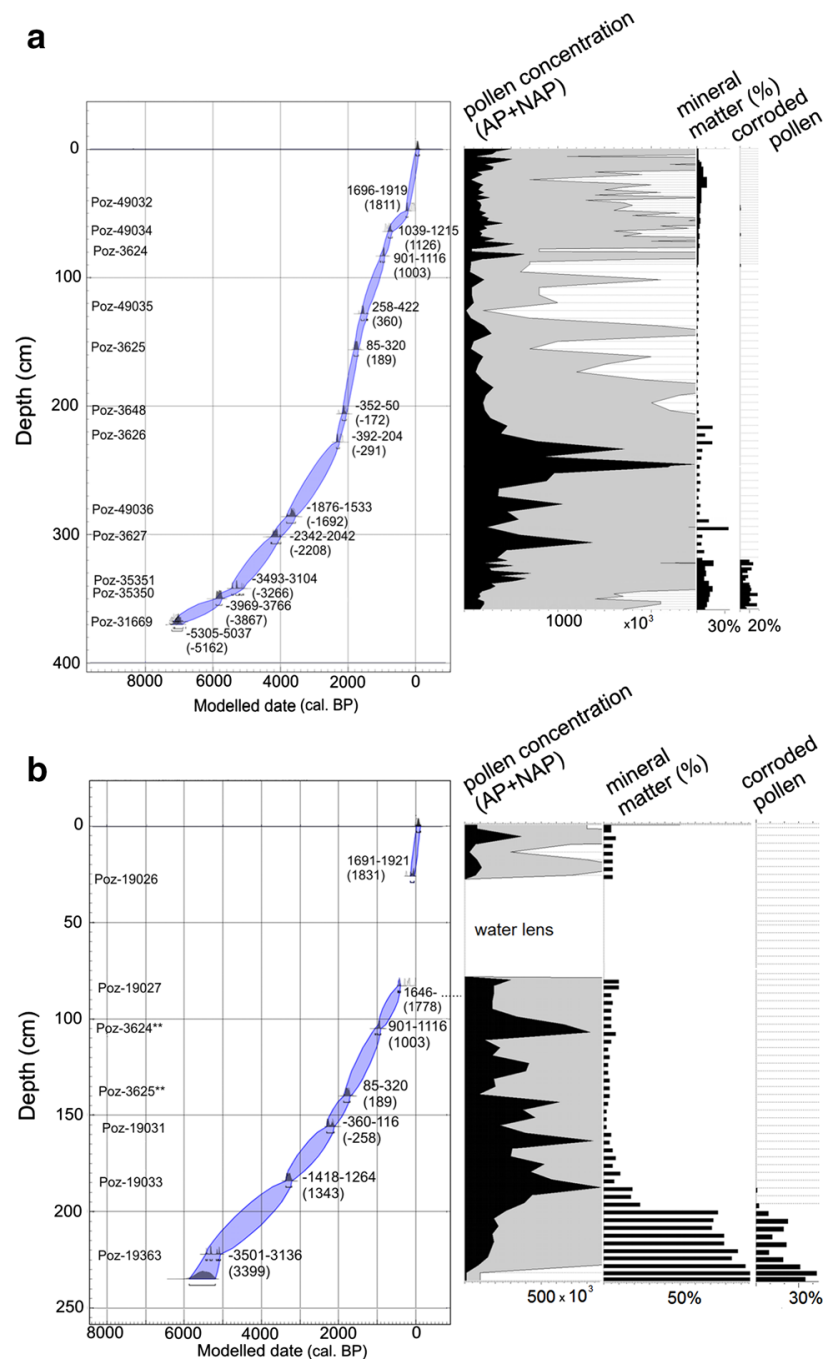

Fig. 2 Age-depth models, total AP+NAP concentrations, content of mineral matter and proportions of corroded pollen for the G/I (a) and G/II (b) profiles. The age-depth models are based on calibration with to OxCal 4.2 (Bronk Ramsey and Lee 2013). For each dated depth the calibrated age range $(2 \sigma)$ and its weighted mean expressed as a $\mathrm{BC} / \mathrm{AD}$ date are shown. In the G/II model two additional dates from the G/I site (marked by asterisks) were adopted ombrogenic mires. The present-day vegetation reflects ecosystem disturbances resulting from a ditch dug along the bog margin. A large area of the bog surface is overgrown by Molinia caerulea and various species of Carex (C. canescens, C. echinata, C. paniculata). Juncus effusus, Dryopteris carthusiana, Menyanthes trifoliata and Comarum palustre form patches on wet disturbed fragments and along the bog margins. In the central part of the bog, Oxycoccus palustris, Andromeda polifolia and Ledum palustre are common. Sphagnum palustre, S. russowi and $S$. squarrosum are among the most frequent species in the moss layer. Scattered mature and juvenile specimens of Betula pubescens and Pinus sylvestris are present.

The G/II site can be classified as a forest hollow. It is c. 0.15 ha $(50 \times 20-30 \mathrm{~m})$ in surface area. Patches of rushes with Scirpus sylvaticus, J. effusus, Thelypteris palustris, Peucedanum palustre and Agrostis canina occur towards the bog margins. Among sedges, the most frequent are $C$. canescens, C. echinata, C. nigra and C. rostrata. In the central part of the bog, C. palustre and M. trifoliata are common; the moss layer consists of, for example, S. palustre, S. russovi, S. squarrosum and Polytrichum strictum. In places, Frangula alnus encroaches on the bog surface.

\section{Materials and methods}

Both profiles were collected in the central parts of the peat bogs, using an Instorf sampler with a diameter of $10 \mathrm{~cm}$. A preliminary description of lithology was made in the field and then supplemented according to examination of the sediments in the laboratory and the results of loss of ignition (LOI) and macrofossil content. Sediment descriptions follow a simplified Troels-Smith system (Aaby and Berglund 1986).

Pollen samples were analysed at 2, 4 or 6-cm intervals. Sediments $1 \mathrm{~cm}^{3}$ in volume were boiled in $10 \% \mathrm{KOH}$ and then acetolysed (Fægri and Iversen 1989). If necessary, samples were first processed with HF to remove siliceous matter. Lycopodium tablets (University of Lund) were added for calculating pollen concentration (Stockmarr 1971). At least 1,000 pollen grains per sample were counted. Pollen and spore identification followed Moore et al. (1991), Beug (2004) and Punt et al. (1976-2003). The reference collection at the Laboratory of Palaeoecology and Archaeobotany, University of Gdańsk, and photographic materials (Reille 1992-1998) were consulted. Percentages of dry-land taxa and microcharcoal particles $>20 \mu \mathrm{m}$ were calculated using the AP+NAP sum (excluding corroded pollen grains and sporomorphs of aquatic and wetland plants). Non-pollen palynomorphs (NPPs) (van Geel 2001) were counted along with the pollen and calculated against the AP+NAP (all taxa) + NPPs sum. 


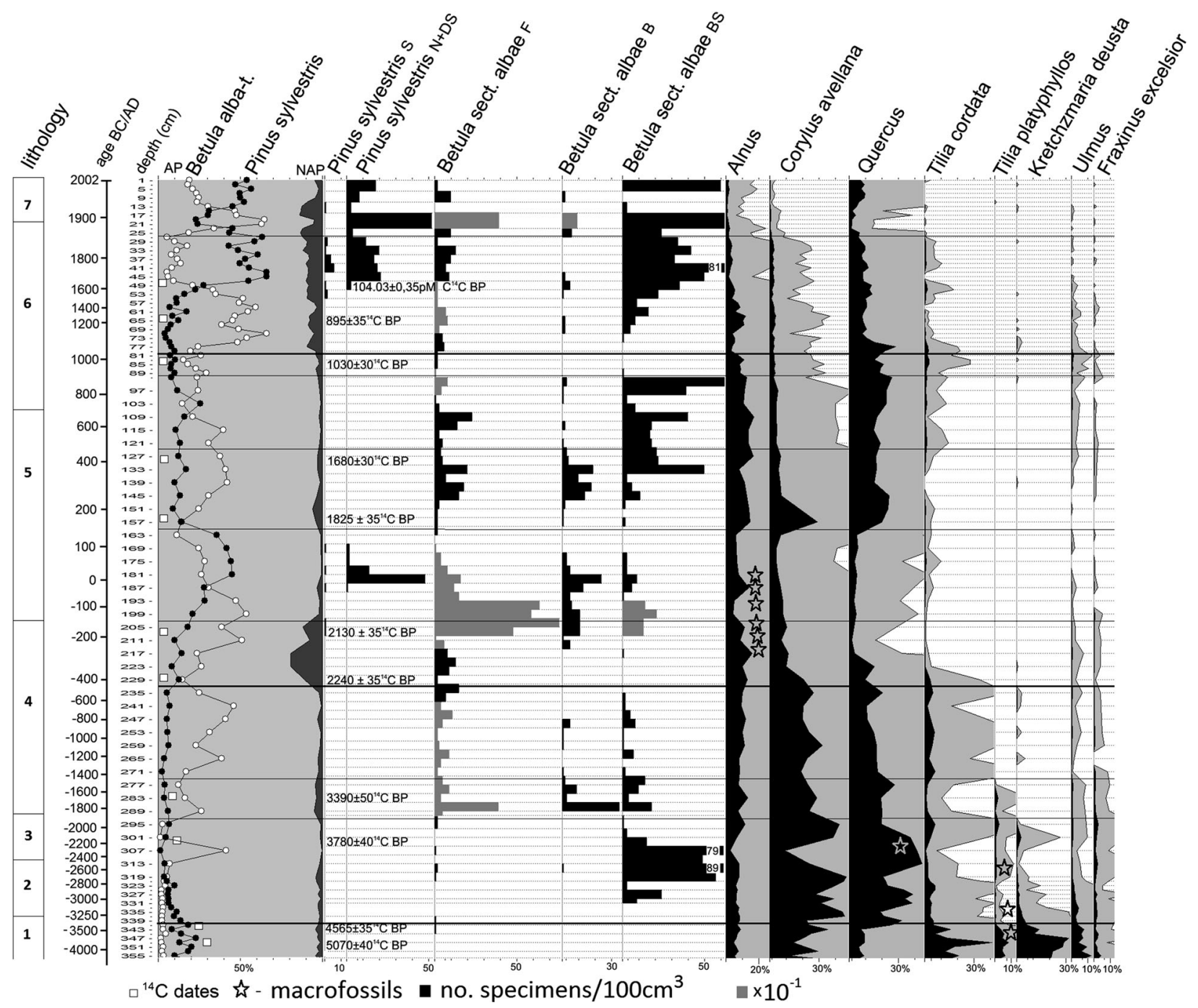

Fig. 3 Combined pollen, NPPs and macrofossil diagram for dry-land taxa in the G/I profile. For the lithological units see Supplementary material 1 Table $1 ; B$ bract, $B S$ bud scale, $D S$ dwarf shoot, $F$ fruit, $S$ seed $N$ needle

For macrofossil analysis, sediments were cut into slices $4-5 \mathrm{~cm}$ thick (100-150 $\mathrm{cm}^{3}$ in volume) taking into account lithological limits. The material was immersed in water with a small admixture of $\mathrm{KOH}$ for $24-48 \mathrm{~h}$ and then wetsieved on a column of sieves with $0.2,0.5$ and $2.8 \mathrm{~mm}$ meshes. The residue was screening under $16 \times$ magnification. Identification of macrofossils was based on several specific keys and atlases and confirmed using the reference collection in the Laboratory of Palaeoecology and Archaeobotany at the University of Gdańsk.

LOI was determined at the same intervals as used for the pollen analysis. Sediments were dried at $105^{\circ} \mathrm{C}$ for $24 \mathrm{~h}$ (dry weight) and then combusted at $550{ }^{\circ} \mathrm{C}$ for $8 \mathrm{~h}$.

The chronology of the palaeoecological events is based on 17 radiocarbon dates (AMS) performed at the Poznań Radiocarbon Laboratory, Poland (Supplementary material 1
Table 1). Remains of terrestrial plants were used for dating purposes. Calendar years were obtained using the calibration curve (Reimer et al. 2013) and OxCal software (version 4.2; Bronk Ramsey and Lee 2013). The weighted mean of the dates was calculated within the range of $2 \sigma$ probability and then used for the estimation of age per sample.

\section{Results}

\section{Lithostratigraphy and chronostratigraphy}

\section{Gotębiewo I}

The G/I profile is composed of peat differentiated into seven lithological units (Supplementary material 1 


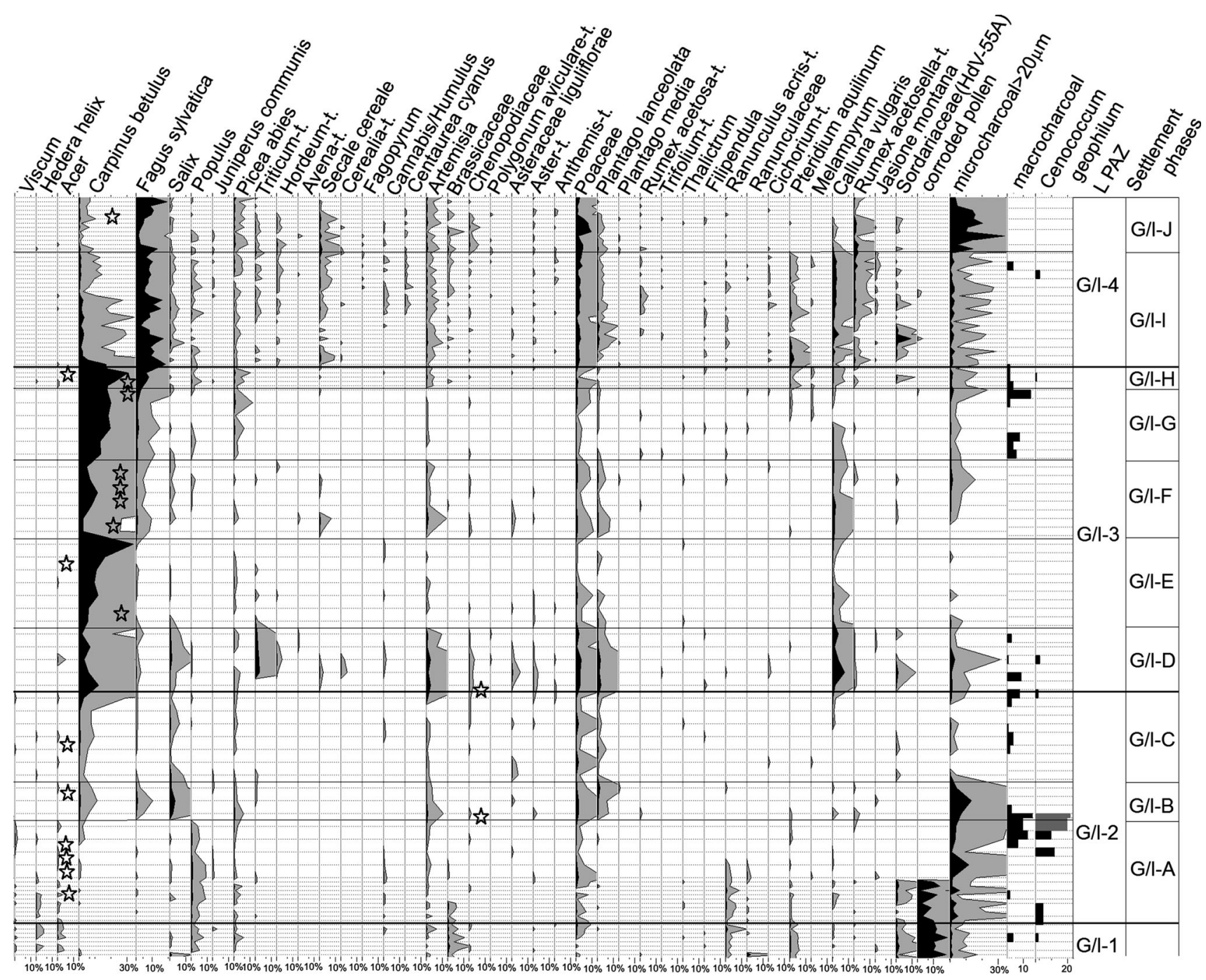

Fig. 3 continued

Table 2). Herbaceous peat in a condition of high to medium decomposition is the main element in the lower section of the profile up to $208 \mathrm{~cm}$. The upper section is built up of Sphagnum peat with a variable proportion of Eriophorum vaginatum and Ericaceae remains. The highest content of mineral matter occurs at the 295-289 and 229-217 cm depths, and in the top of the profile (Fig. 2a). The profile covers the period of the last c. 5,800 years. The age/depth model (Fig. 2a) shows a variable peat accumulation rate that is higher in the upper part of the profile $(0.7-1.85 \mathrm{~mm} /$ year) and lower in its bottom part $(0.31-0.38 \mathrm{~mm} /$ year $)$ with an extremely small deposition rate of about $0.13 \mathrm{~mm} /$ year, concurrent with increased mineral matter and corroded pollen, at the depth of 355-337 cm (c. 3800-3300 вс); we suggest a potential hiatus within this section. Drops in peat accumulation rate suggested by peaks of pollen concentration of most taxa (Supplementary material 2 Fig. 1a) is postulated for the sections at the depths of
260-235 and $145-139 \mathrm{~cm}$ (c. $1100-500 \mathrm{BC}$ and $\mathrm{AD}$ 280-300).

\section{Gotębiewo II}

The G/II profile has been divided into five lithological units (Supplementary material 1 Table 2) representing mineral deposits (235-196 cm) and dark brown, highly decomposed herbaceous/Carex peat $(196-0 \mathrm{~cm})$. A water lens $(80-28 \mathrm{~cm})$ separates the lower from the upper part of the core. This profile covers the period of the last 5,300 years. Although the age/depth model (Fig. 2b) seems to illustrate a generally low but stable deposition rate $(0.2-0.36 \mathrm{~mm} /$ year), the sediments of this site are not an ideal source for precise chronological reconstruction. Strong variation in the pollen concentration concurrently for most taxa (Supplementary material 2 Fig. 1b) enabled us to identify at least the main sections where peat deposition rate was extremely 
low or even some minor hiatuses may occur: $180-160 \mathrm{~cm}$ (c. 1300-400 BC), around $130 \mathrm{~cm}$ (early part of the Roman period) and around $100 \mathrm{~cm}$ (early Middle Ages). Thus, especially in these sections dating based on the model (Fig. 2b) is uncertain. Therefore, in our description of some environmental events we are using the rather more detailed chronology reconstructed in G/I profile.

\section{Changes in dry-land vegetation}

The distinct similarity of both pollen diagrams allows us to provide a joint description of vegetation history in the vicinity of the G/I and G/II sites. In each profile, four local pollen assemblage zones (LPAZ) have been identified; description of human activity is based on settlement phases delimited in both diagrams: $\mathrm{G} / \mathrm{I}(\mathrm{A}-\mathrm{J})$ and $\mathrm{G} / \mathrm{II}(\mathrm{A}-\mathrm{H})$ (Figs. 3, 4; Supplementary material 1 Tables 3, 4). We present correlation of particular zones and settlement phases in both profiles in Supplementary material 2 Fig. 2.

Tilia-Ulmus LPAZ (G/I: 3800-3300 вC; G/II: >3300 вC) illustrates the final stage of the Tilia-dominated forest development, described in detail in an earlier paper (Latałowa et al. 2013).

At the beginning of the period covered by the QuercusCorylus LPAZ (3300-460 BC) an oak-hazel community replaced the Tilia forest. Very high proportions of oak and hazel pollen reflect population expansion of both trees directly around the sites and in this respect, strong, temporal decline of Corylus (2400-2200 BC) is worthy of notice. In this forest, Tilia persisted as an important admixture until the end of this period while Ulmus and Fraxinus were continuously decreasing. The local presence of Acer platanoides is proven by macrofossils. Pinus has practically disappeared. Even, except for the phase G/I-B (1700-1450 BC), pollen typical of settlement activity occurs in very low frequencies, the palaeoecological data suggest permanent disturbances of the local forest through the use of fire. The forest destruction/regeneration phases are reflected by fluctuating mesophilous tree pollen, the continuous Populus curve, high frequencies of micro- and macrocharcoal and high peaks of Betula pollen and macrofossils We interpret the culminations of Betula in this pollen zone, as well as in the remaining parts of both profiles, as a coupled effect of its expansions in the surroundings of the sites due to forest disturbances and subsequent spread onto the mires, especially in the drier periods. The causal link between the declines of deciduous trees and the Betula expansions are illustrated by the negative correlation between these elements in the pollen concentration diagrams (Supplementary material 2 Fig. 1).

Carpinus-Quercus-Betula LPAZ (460 BC-AD 1030) illustrates development of the forest community in which Corylus has been replaced by Carpinus. Changing proportions of
Quercus, Betula and Pinus were characteristic for this phase. Three culminations of hornbeam pollen (more pronounced in the G/II profile) separated by two depressions filled by high culminations of Betula pollen are shown in both percentage and pollen concentration diagrams. This period was characterized by a variation in human activity around the sites. The most pronounced human impact phase (G/I-D: 460-140 BC; G/II-B: $600-300 \mathrm{BC}$ ) is expressed by a strong decline in deciduous tree pollen coinciding with a distinct increase in Betula and culminations of anthropogenic indicators; a short rise of Carpinus at the expense of Quercus is characteristic for the beginning of this phase. The pronounced peaks of charcoal particles indicate the use of fire for forest management. An economy based on agriculture is illustrated by the high amount of pollen from cereals (Triticum-type, Hordeum-type, Avenatype, and a single Secale pollen grain). The development of pastures on fresh and more fertile habitats (Plantago lanceolata) and on poor sandy soil (Calluna) indicates animal husbandry. Grazing in the nearby wood is suggested by an increasing frequency of coprophilous fungi spores (Sordariaceae-type). The general synanthropization of the flora and vegetation is illustrated by high proportions of weeds, especially of Artemisia, and an increase in NAP palynodiversity. In a short regeneration phase (G/I-E, G/II-C: 140 BC-AD 160), Betula, Pinus and then Carpinus played a major role in the subsequent stages of the secondary succession. Corylus and Quercus did not recover throughout this period, remaining as a very minor admixture in the local forest. Scattered pollen of cereals and $P$. lanceolata may suggest the persistence of some settlement activity in a more distant area.

The next, rather weak settlement expansion (G/I-F; G/IID: AD 160-450) took place in the Roman Iron Age. It started with a forest clearing (strong Carpinus decline) and agriculture development (small peaks of Secale, P. lanceolata, Artemisia and Calluna pollen). Then human activity continued with much lower pressure, probably through coppicing, which enabled gradual recovery of the oakhornbeam forest initiated by a brief expansion of Corylus. During this phase, Pinus distinctly declined, while Fagus started to increase its population.

Further distinct regression in settlement (G/I-G; G/II-E: $\mathrm{AD}$ 450-900) resulted in the development of the most mature form of the Quercus-Carpinus forest in which Betula and Pinus were in a small admixture and the proportion of Fagus was still insignificant. Scattered pollen of $P$. lanceolata (both profiles) and single pollen grains of Triticum-type and Hordeum-type (G/II profile) suggest persistence of settlement in the region. At around AD 900 (G/IH, G/II-F: AD 900-1030), Fagus started to expand after the forest disturbances, especially because of damage of oak stands. However, only limited pollen of cultural indicators (including Secale) does not prove development of settlement close to the sites. 


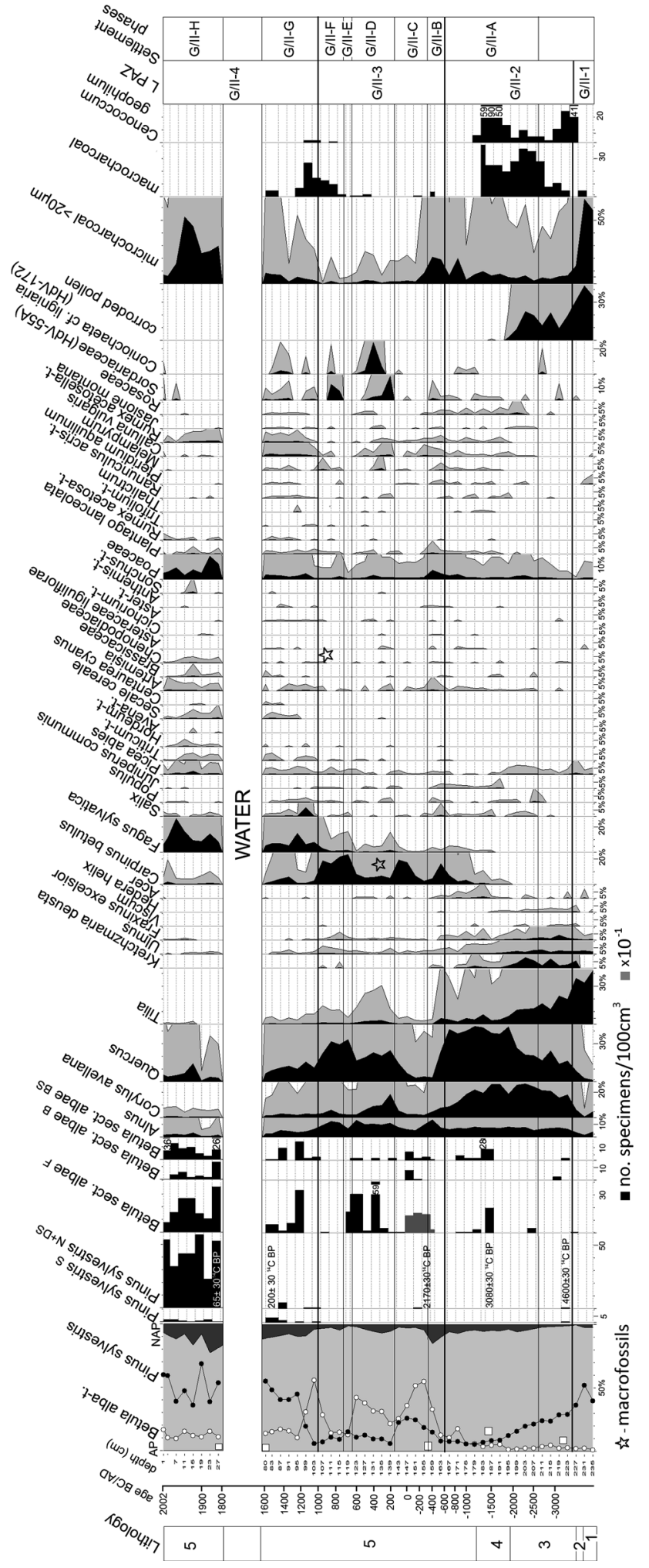

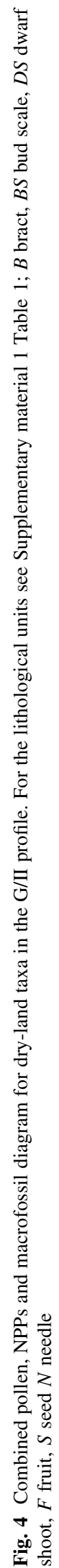




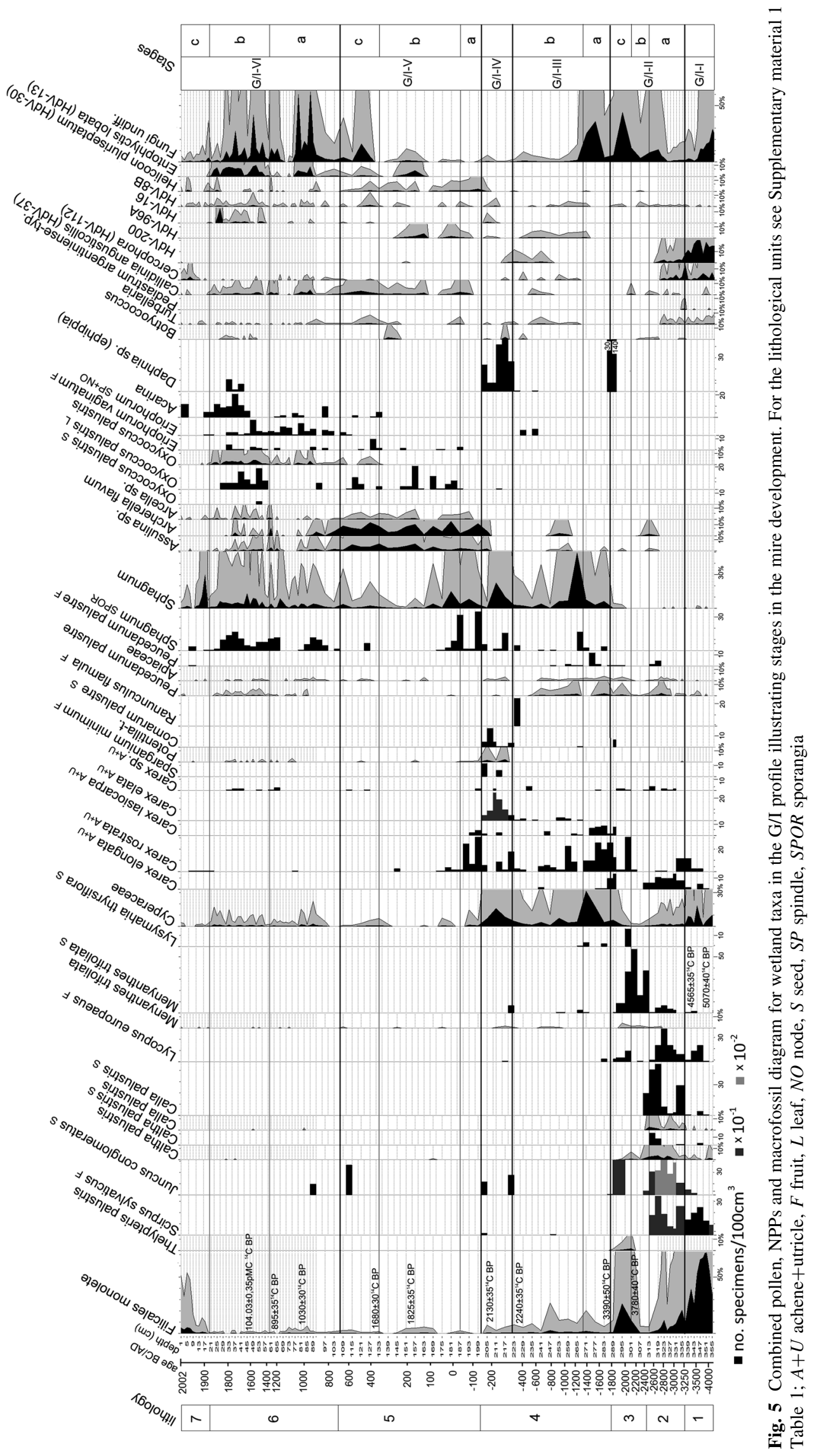


Fagus-Pinus LPAZ (AD 1030 to present) reflects the history of a forest developing under moderate human activity through the medieval period and modern times $(\mathrm{G} /$ I-I, G/II-E: AD 1030-(?) 18-19th century and G/I-J, G/IIF: (?) 19-20th century). After destruction of the oak-hornbeam forest, Fagus continued to expand, but in the most disturbed areas first Betula and then Pinus played an important role in the forest regeneration. Strong forest disturbances and very weak evidence for agriculture (low frequency of cereal pollen types and indicators of open pastures, e.g. P. lanceolata) and increased frequency of coprophilous fungi spores (Sordariaceae-type.) suggest that the area was most probably used mainly for timber extraction and as a wood pasture. Regular occurrence of Pteridium, Melampyrum and Calluna and the presence of microcharcoal are probably indicators of the use of fire in forest management. Pollen data illustrate several fluctuations of particular tree proportions in the forest cover, which reflect changes in intensity and probably methods of forest use; however, we have no adequate dating for this part of the profiles to present a more detailed chronology of these events.

\section{Changes in the wetland ecosystems as a proxy for palaeohydrological reconstruction}

\section{Gotebiewo I}

Micro- and macrofossil remains of the organisms co-existing in the past wetland ecosystems left an imprint of six stages (G/I- I-VI) and some minor shifts (sub-stages) in the hydrological history of the G/I site, during the period under concern (Fig. 5; Supplementary material 1 Table 5).

Dry conditions on the mire are postulated for the period c. 3800-3300 BC (G/I-I). High proportions of corroded pollen (Fig. 3) and remains of a fungus developing on drying-up plant material $(\mathrm{HdV}-200)$ indicate that the vegetation dominated by Filicales and Scirpus sylvaticus was a subject of seasonal drought. Very low peat accumulation rate $(0.13 \mathrm{~mm} /$ year $)$ calculated for this section may suggest a discontinuity of the sediments. After c. 3300 вC (G/I-IIa) water level rose as shown by the development of vegetation with Carex rostrata, C. elongata and Calla palustris. A further wet shift c. 2500-2100 BC (G/I-IIb) is marked by expansion of Menyanthes trifoliata and decline of e.g. S. sylvaticus, Juncus conglomeratus and Lycopus europaeus. A new expansion of Filicales (Thelypteris palustris) and $J$. conglomeratus, and a decline in peat accumulation rate $(\mathrm{G} /$ I-IIc), suggest a drier phase c. 2100-1700 вс.

This originally minerotrophic mire has gradually transformed into an ombrogenic peat-bog. The ombrotrophication started between 1700 and 1300 BC (G/I-IIIa) when Carex lasiocarpa and Sphagnum become important elements of the local vegetation; however minerotrophic elements, with $C$. rostrata as the most common, were still important during the whole stage of the transitional-type peat-bog development (G/I-III: 1700-300 BC). This succession was interrupted by a wet event (G/I-IV: 300-100 BC) when ground water-table growth enabled development of water pools as demonstrated by large numbers of Daphnia sp. ephippia and fruits of Sparganium minimum. Patches of mire vegetation were formed by Carex elata, $C$. rostrata and Comarum palustre growing among Sphagnum lawns.

Just before the first century $\mathrm{AD}$ the reduced input of minerogenous water brought about further ombrotrophication and the development of an ombrogenic bog (G/I-V: 100 BC-AD 670); however some minerotrophic elements $(C$. rostrata) persisted in the local vegetation till c. 100-40 ВС (G/I-Va). The most characteristic signature of the G/I-V stage is the fluctuating occurrence of Oxycoccus palustris and of testate amoebae such as hygrophilous Archerella flavum and Assulina spp., indicating a drier bog surface. Several indicators of unstable moisture conditions (e.g. Arcella, Callidina angusticollis, E. vaginatum) confirm climate fluctuations with a general wetter trend (e.g. HdV96A has been replaced by Entophlyctis lobata) in the period AD 370-670 (G/I-Vc).

The instability of hydrological conditions increased in the period from $A D 670$ to the present $(\mathrm{G} / \mathrm{I}-\mathrm{VI})$. In the section 106-60 cm (G/I-VIa: AD 670-1320) A. flavum distinctly declined and sclerenchymatic spindles of Eriophorum and fruits of E. vaginatum became more frequent, indicating a drop in the mire surface wetness. This rather dry phase was interrupted by a wet event recorded at the 86-75 cm depth, (AD 950-1080). In this section, first $A$. flavum, then E. lobata and $C$. angusticollis increase. At the depth of 60-20 cm (G/I-Vb: AD 1320 to (?) 18-19th century), several indicators of wetter conditions re-appear (e.g. E. lobata, $\mathrm{HdV}-16$, and $O$. palustris), reflecting a more positive water balance than in the preceding period. The most recent stage (G/I-VIc: (?) 19-20th century) was characterized by disturbances of the bog surface, lowering of the water table and increased trophy. In this period Sphagnum, E. vaginatum, $O$. palustris and E. lobata declined, and Filicales started to spread. We do not put a more exact age to the G/I-VIb/c limit because it is beyond our dating capacity.

\section{Gotebiewo II}

The paludification of this small depression started at around 3,300 years BC. The minerogenous conditions prevailed during the history of the site, however, tendency toward ombrotrophication occurred as well. Our data illustrate three main stages (G/II-I-III) and several minor 


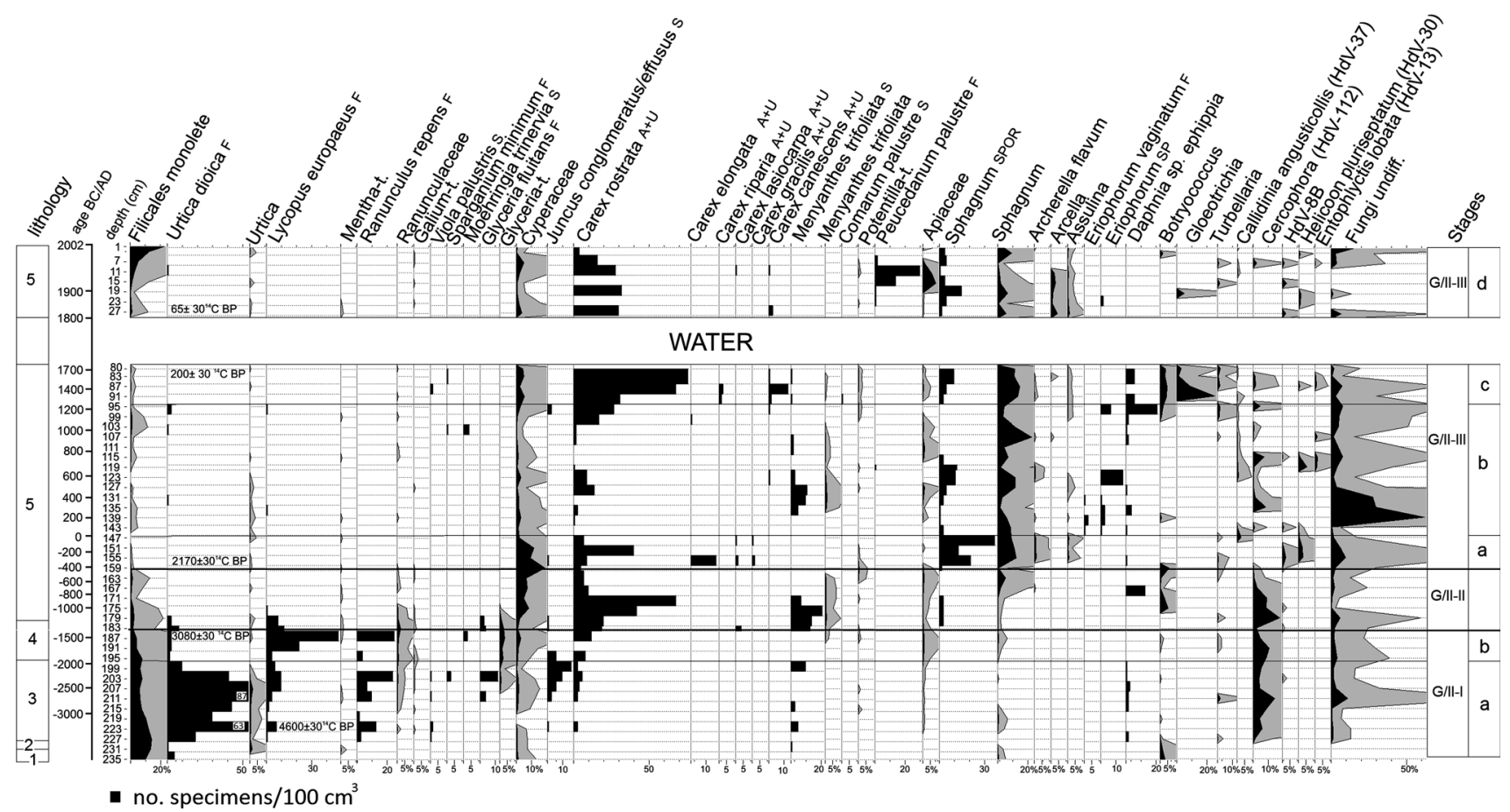

Fig. 6 Combined pollen, NPPs and macrofossil diagram for wetland taxa in the G/II profile illustrating stages in the mire development. For the lithological units see Supplementary material 1 Table 1; $A+U$ achene + utricle, $F$ fruit, $S$ seed, $S P$ spindle, SPOR sporangia

shifts (sub-stages) in the vegetation development (Fig. 6; Supplementary material 1 Table 5).

At around $3300 \mathrm{BC}$, an increased moisture of mineral ground and input of organic matter due to erosion of soil in the surroundings of the site (high amounts of mineral matter, high deposition of Coenococcum geophilum, charcoal particles and corroded pollen), resulted in the eutrophic fen development (G/II-I: 3300-1300 BC). In the initial period (G/II-Ia: 3300-1900 вC) Urtica dioica and Filicales with Ranunculus repens, L. europaeus, Glyceria fluitans and $J$. conglomeratus were the most common species. The hydrological conditions were unstable, as indicated by incidental occurrences of aquatic organisms (Daphnia sp., Acarina, S. minimum) and species typical of mesotrophic habitats $(M$. trifoliata). In the following period $(\mathrm{G} / \mathrm{II}-\mathrm{Ib}$ : 1900-1300 BC) due to reduced erosion and accumulation of organic sediment, $U$. dioica declined and trophy of the local habitats decreased. A small peat accumulation rate in the whole G/II-I stage could have arisen from a very low potential of that vegetation type for deposit formation.

Distinct change on the mire took place at around 1300 BC (G/II-II: $1300-400$ вC) when a mesotrophic rush vegetation dominated by $C$. rostrata developed. Appearances of Botryococcus and Daphnia remains point to a wet phase. Stage G/II-III (400 BC to present) with high frequency of Sphagnum and temporal presence of E. vaginatum, Assulina spp. and A. flavum, illustrates a further trend towards oligotrophication of the local habitats following a decrease of minerogenous water input. During this stage alternating wet and dry shifts occurred. However, due to the low peat accumulation rate and thus inadequate dating in this section of the profile, the chronology of these events, given below according to the model (Fig. 2b), is not precise. We may only suggest that oligotrophication on this site started between 400 and $20 \mathrm{BC}$ when the similar process in $\mathrm{G} / \mathrm{I}$ accelerated c. 100-40 BC. A stage in the water rise (G/IIIIIc: AD 1200-1770), as shown by a high frequency of aquatics (e.g. Daphnia sp., Botryococcus and Gleotrichia) and the presence of a water lens, correlates well with a wet period reflected in the neighbouring site as the G/I-Vc stage. At the very top of the profile disturbances of the mire surface are suggested by the expansion of Peucedanum palustre and Filicales.

\section{Discussion}

\section{Hydrological changes}

The wet and dry shifts recorded on our mires may illustrate both changes in the regional hydroclimatic conditions and local fluctuations of the ground water table; the latter could arise from disturbances in the forest cover in the surroundings of the sites. The aim of the discussion on this topic is an attempt to separate the palaeohydrological signals originating from each factor. 
Fig. 7 Palaeoecological events recorded in the Gołębiewo sites. Changes in forest composition, the main forms of human impact on forest cover, settlement intensity and pollen-based evidence of economic activity, and relative changes in hydrological conditions on the mires are shown. Our palaeohydrological data apparently correlate with some widely recognized climatic shifts (e.g. Bond et al. 1997; Magny 2004; Büntgen et al. 2011); RWP the Roman Warm Period, $M P$ cooling in the migration period, $M C A$ the medieval climate anomaly, LIA the little ice age

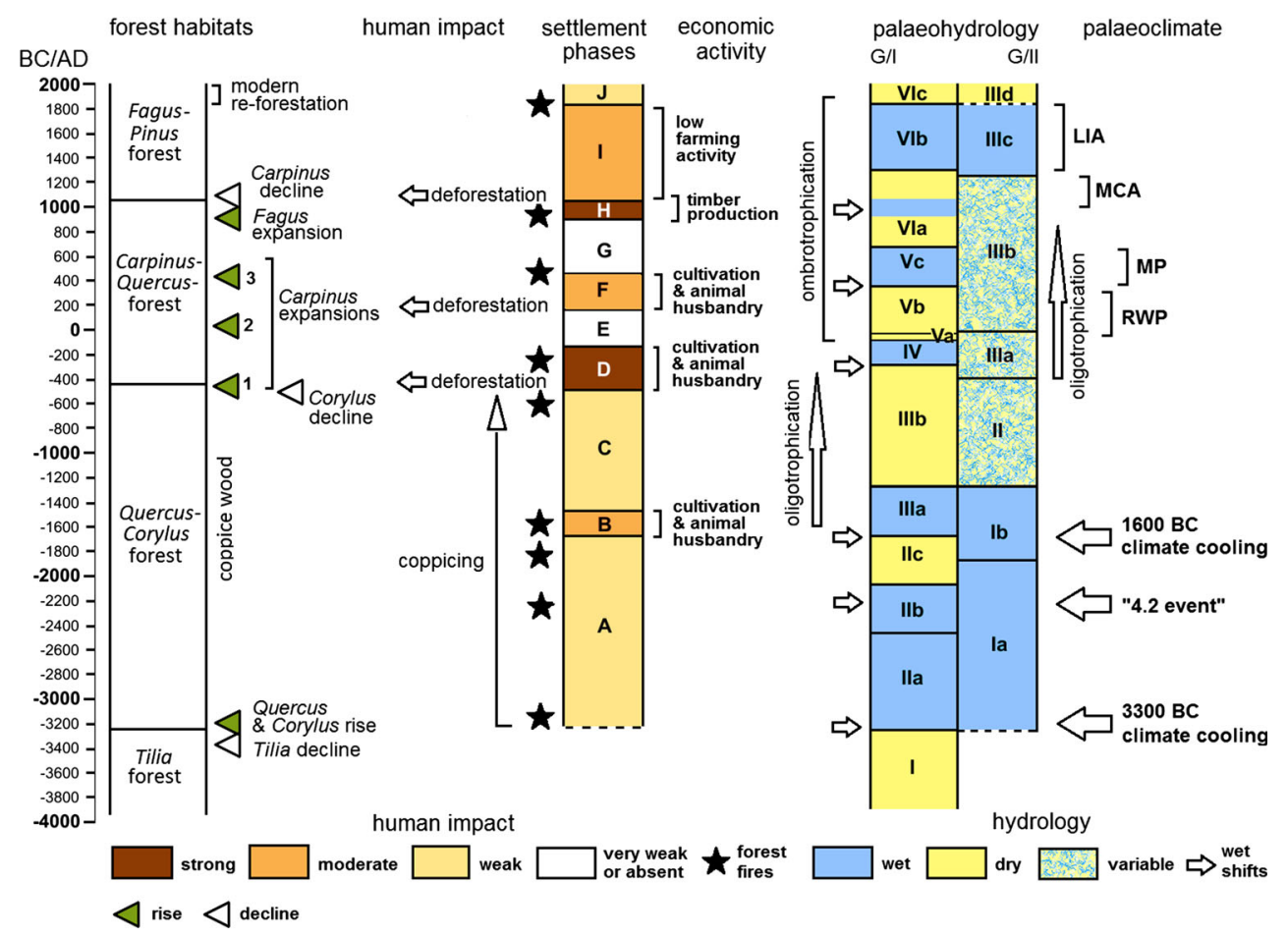

The wet phase dated to c. $3300 \mathrm{BC}$ at both sites probably reflects the relatively cold and wet events in the period 3600-3300 BC recorded not only in the regional data (Lamentowicz et al. 2010; Pedziszewska et al. 2015) but also in the wider areas of central Europe (Magny 2004; Magny and Haas 2004) (Fig. 7). In the subsequent period, the hydrological budget of the mires was positive, with a distinct wet phase at around 2500-2100 BC, which correlates well with the cooling of the " 4.2 climate event" (IRD-4) (Bond et al. 1997), reflected also in the regional data (Pędziszewska et al. 2015). The wet episode at about 1700 BC (G/I site) coincides with a distinct human impact phase of the Bronze Age pointing to forest disturbances as a potential factor for the hydrological change. On the other hand, increased climate humidity around this date has been reported in many studies from northern (Hammarlund et al. 2003; Jessen et al. 2005), western (Charman et al. 2006) and central Europe (Magny 2004; Holzhauser et al. 2005); a wet phase at around 1700-1300 BC also has been described by Gałka et al. (2013) from a raised bog in the Kashubian Lake District. This age horizon is claimed as the time of one of the major Holocene climate shifts reflected in the European pollen data (Giesecke et al. 2011).

At the G/I site, a distinct water table rise (c. 300-100 вс) took place concurrently with an occupation phase at around 460-140 вс. This most intensive (on the scale of the whole history of these sites) settlement activity involved strong disturbances of the forest habitats (see below), including forest thinning immediately around the sites. This disturbance probably resulted in a ground water level rise and a surface water run-off, and finally inundation of the local depressions. It is, however, worthy of note that this wet event coincides with the humid phase shown by the tree ring-based reconstruction of central European climate (Büntgen et al. 2011). After c. 100 BC, the delivery of ground water at the G/I site stopped, stimulating development of an ombrophilous bog vegetation. Concurrently, Sphagnum and some species typical of ombrogenic bogs spread onto the G/II site. A dry and warm climate around the beginning of the first millennium $\mathrm{AD}$ (the Roman Warm Period) (e.g. Esper et al. 2012; McCormic et al. 2012) might be involved in this shift.

From c. AD 370 up to about AD 670, climate fluctuations with a general wetter trend occurred in the G/I site. A similar trend is observed in the G/II site. Our data conform well to the palaeoclimatic reconstructions indicating climate cooling after $\mathrm{AD} 200$ and the persistence of colder and wet conditions up to $\mathrm{c}$. the 7 th century, with some minor shifts in temperature and precipitation (Büntgen et al. 2011; Esper et al. 2012; McCormic et al. 2012).

At about AD 670, the moisture of the G/I bog surface decreased and dry conditions prevailed up to $\mathrm{AD} 1320$, except for a short wet event roughly dated to AD 950-1080. Here again, the coupled effect of the local deforestation and increased precipitation shortly before AD 1000 (Büntgen et al. 2011) may explain the result. After AD 1320 a new wet stage appeared. It probably reflects the Wolf minimum (1280-1350), which started a cluster of four 
grand solar minima coinciding with the cooling of the little ice age (AD 1350-1850) (Steinhilber and Beer 2011). The most recent time, which cannot, however, be dated in more detail, is characterized as a rather dry phase and a period of very clear disturbances on the mires.

\section{Human and climatic factors as ecological drivers of the forest succession}

According to knowledge to date, in north-central Europe early and middle Holocene forest dynamics were driven mainly by natural factors: migration biology, climate change, soil development and inter-species competition. In the late Holocene, human impact was among the most important factors (Birks 1986). However, many open questions remain regarding the role of particular natural agents, especially climate and different kinds of anthropogenic activity, on transformation of forest composition in various geographic regions. We provide the results from a transitional area between western and eastern Europe with respect to climate, vegetation and cultural development.

Our present study starts with the decline of the midHolocene Tilia forest, this being the subject of an earlier paper (Latałowa et al. 2013). The Tilia forest began its major decline at around $3300 \mathrm{BC}$, along with the population expansion of Quercus and Corylus. The timing of this process coincides with a climate cooling (Magny 2004), which seems to be reflected in both Gołębiewo profiles as a wet phase (Fig. 7). In the surroundings of our sites, the long-term infection of the local Tilia population by Kretzchmaria deusta (Latałowa et al. 2013) could be an additional factor enhancing its vulnerability to the climate change. On the other hand, evidence is ample for human impact as an important trigger reducing Tilia stands (Aaby 1983; Andersen 1984; Grant et al. 2011; Bradshaw and Sykes 2014). Also in our record, the Tilia decline is associated with an increased number of micro- and macrocharcoal particles and the first scattered pollen grains of $P$. lanceolata and Triticum-type, indicating farming activity of the Neolithic tribes. The rapidly increasing amount of pollen of light-demanding taxa such as Quercus, Corylus and Populus suggests coppicing of the forest (cf Aaby 1983; Rösch et al. 2014). According to Waller et al. (2012), coppicing strongly reduces Tilia flowering. The study of the nutritive value of woody species recorded among remnants of leaf fodder in archaeological sites indicates that Tilia leaves are of the highest quality in this respect (Hejcmanová et al. 2014) whereas Aaby (1983) had suggested that cattle browsing on young shoots of Tilia could be among the reasons for its decline. In contrast, cattle grazing could promote hazel at the expense of lime because its leaves are less palatable (Haeggström 1990); a high frequency of coprophilous fungal spores in our profiles should be recalled in this respect. We may also assume that different kinds of selective usage of lime, e.g. for bast, could reinforce the process of its decline. Although its proportions were much reduced, lime was still an important constituent in woodland, covering the Gdańsk Upland up to about $460 \mathrm{BC}$, and it survived as a small admixture in the local ecosystems until recent times.

The Quercus-Corylus coppice wood was probably the main vegetation type close to our sites up to the pre-Roman Iron Age. From c. 1700 BC, Betula started to expand following an increasing intensity of human impact. In contrast to the findings of many other studies, Betula expansions took place also in the periods with a low charcoal record, indicating that it was not necessarily triggered by the use of fire. Probably felling trees formed gaps facilitating the establishment of birch. Also, a potential shortening of the coppicing cycle could, with time, have a negative impact on hazel and oak fitness and then bring about thinning of the forest, leaving the chance for birch expansion. Various techniques for leaf fodder collecting, producing different changes in forest communities and affecting pollen production and dispersal in different ways, might also be among the important factors here. Shredding, even if repeated regularly, would not limit flowering and distribution of tree pollen. By contrast, pollarding prevents flowering if frequently repeated (Rackham 1980; Andersen 1988). Both methods were commonly used in central and northern Europe up to historical times and in some areas until recently (Rackham 1980; Andersen 1988; Austad 1988). Based on our pollen data, we suggest coppicing with shredding as the main method of leaf fodder gathering in the period before the Betula expansion (up to c. $1700 \mathrm{BC}$ ) and the prevalence of pollarding and more intensive felling of trees in the later periods with high birch proportions.

The Quercus-Corylus phase continued for a relatively long period, and after the initial reduction of both oak and hazel in favour of birch at around 1700 вс (the Bronze Age human impact phase), a proper Corylus decline took place much later than in many other regions, correlating with the expansion of Carpinus at c. 460 BC. The low level of agriculture development could be among the reasons for this apparent delay, also recorded in other profiles from the Kashubian Lake District (Pędziszewska et al. 2015). This explanation is in line with the earlier view of RalskaJasiewiczowa et al. (2003), who opted for the anthropogenic impact as a cause for the Corylus decline in central Europe (summarized by Giesecke et al. 2011). On the other hand, a strong, episodic Corylus fall (G/I site) following the well-known cool climatic " 4.2 event", and its large, but short-lived, last expansion in a warm Roman Period suggests that in this area hazel might be rather sensitive to climate fluctuations. Therefore, we may expect that the reduced flowering and fructification in cooler climatic 
conditions, concurrent with increasing needs for hazelnuts (cf. Regnell 2012) by the people living in this area, could be among the factors triggering both Corylus declines at around 1700 and $460 \mathrm{BC}$.

The initial, small-scale population expansion of Carpinus (together with Fagus) at about 1700 BC, and then the proper expansion of this tree at $460 \mathrm{BC}$, were clearly related to the Corylus declines and increased opening of the landscape due to more intense human activity. Carpinus and Corylus in our profiles are negatively correlated, indicating that hornbeam replaced hazel in the local woodland. Increased animal pasturing in coppiced woods could be one of the potential factors for the population expansion of hornbeam after at least about 1,500 years of its limited presence in the forest communities. Carpinus is the most resistant tree against browsing, being a strong competitor under conditions of herbivore pressure (Kuijper et al. 2010).

Both pollen diagrams show three Carpinus pollen culminations, indicating its vigorous population expansions and subsequent limitation during the 1,200-year history of the hornbeam-dominated forests. The first Carpinus decline took place around $280 \mathrm{BC}$, almost immediately after its expansion. This event resulted from the settlement activity in the La Tène period, most probably of the Pomeranian culture as confirmed by the archaeological data (Szymańska 1982). Crop cultivation and animal husbandry left patches of deforested land, which after the settlement collapse (140 BC-AD 160) was subject to secondary forest succession with subsequent dominance of Betula, Pinus and Carpinus and only finally the return of Corylus and Quercus. The second Carpinus decline (AD 160) took place in the Roman Iron Age when settlement of the Wielbark culture took place in this area (Szymańska 1982). At that period, local human activity was probably restricted to animal pasturing and timber harvesting. Forest disturbances resulted in the new Betula expansion. In the following period of settlement decline (the Migration Period), Carpinus-Quercus forest developed. This kind of forest community declined sharply in importance at the beginning of the early middle ages when Carpinus was replaced by Fagus.

In recent years, the development of the geographical range and past population dynamics of Fagus sylvatica are among the most thoroughly discussed issues in European palaeoecology (Küster 1997; Magri et al. 2006; Bradshaw et al. 2010). This species has received much attention because of its significance as a forest tree in waste areas of Europe, so the knowledge of its long-term ecology has been considered crucial for predicting future forest dynamics in a changing climate and with anthropogenic interference in many regions (Giesecke et al. 2007; Bradshaw and Sykes 2014). The specific postglacial expansion pattern of $F$. sylvatica, and especially its delayed expansion at the northern fringes of its distribution in southern Scandinavia, have been the subject of many studies indicating a coupled influence of climate and human impact on the dynamics of Fagus at the regional and local scales; the expansion of small local populations took place after human-made disturbances if the climate had become specifically favourable for beech (Bradshaw et al. 2010). Similar conclusions were drawn from the pollen records from Wolin Island, NW Poland (Latałowa 1992). In the present paper, we illustrate the history of Fagus in an area lying close to the present-day eastern geographic limit of the massive beech occurrence, in which area it only started to play a role as a major tree in the last millennium.

Similarly to other studies, it is practically impossible to show the time of Fagus arrival in the area. As in many pollen diagrams from elsewhere, in Gołębiewo Fagus pollen forms "a tail" of low occurrences before its first, small-scale temporal expansion at about $1700 \mathrm{BC}$, which can be interpreted as a scattered local presence of the tree or as long-distance pollen transport (Giesecke et al. 2007; Overballe-Petersen et al. 2013). Pollen data from NW Poland indicate a Fagus expansion wave moving from the west to the east with a delay of more than 1,500 years between the western (Wolin Island) and eastern sites (Gdańsk Upland) (Latałowa 1995; Ralska-Jasiewiczowa et al. 2003). In the eastern sites, beech expansion seems to have been blocked by the earlier vigorous expansion of hornbeam under a regime of coppicing. This kind of forest management strongly promotes Carpinus and restricts Fagus (van der Werf 1991). On Gdańsk Upland, the Fagus population started to increase slowly along with the oakhornbeam forest development during a period of low human activity (most of the first millennium after $1 \mathrm{AD}$ ), but beech remained a minor forest constituent up to about $\mathrm{AD}$ 900. This pattern most probably reflects its low ability to increase its population density (Giesecke et al. 2007).

The beginning of the early medieval expansion of beech was preceded by forest disturbances with fire and then selective removal of oak. In that period (10th-12th century), settlement activity increased, and apart from other needs, a large amount of timber was harvested to build settlements and strongholds in the area of the present city of Gdańsk and its surroundings. Large oak trunks are the main construction material found in the archaeological excavations uncovering settlement layers of that period (Kościński and Paner 2005). Selective extraction and transportation of timber probably resulted in both heavy local disturbance of the ground, facilitating establishment of beech seedlings, and the protection of the habitat from winter frosts and drought by the remaining trees playing the role of a shelterwood, which is important for beech regeneration (Agestam et al. 2003). Once well established, 
beech is a strong competitor with other forest trees, especially hornbeam, through changes in light conditions, soil properties and microclimate (Andersen 1984; Ellenberg et al. 1988).

In historical times, because of its strongly differentiated relief, the marginal zone of the Gdańsk Upland was never converted into cultivated fields or open pastures. However, trees were probably logged, and the area was used as a wood pasture, as suggested by a high frequency of coprophilous fungi spores. In this forest, beech and oak were continuously present as important constituents, even though high fluctuations of Betula and Pinus pollen indicate at least two periods of intense forest disturbancesfirst around the 11-15th century and second in modern times-which were followed by secondary forest succession. It is a matter of further investigation as to what extent their high representation could result from partial protection of mast trees. The continuity of the forest cover on the Gdańsk Upland is documented both by our pollen data and by all available historical maps, on which the edge of the upland is always presented as a large strip of forested land separating two densely settled areas: the plateau of the Upland and the low-lying platform extending towards the sea shore.

\section{Conclusions}

Our results from combining data on the local-scale ecological changes of dry-land vegetation and of mire vegetation driven by hydroclimatic conditions demonstrate that in the investigated area, each of the subsequent late Holocene shifts in dominating forest communities took place during relatively short periods. Shifts from the Tilia dominating forest to a Quercus-Corylus plant community at around $3300 \mathrm{BC}$ and the expansion of Fagus c. AD 900 were most probably driven by the coupled effect of climate change and human activity. The final Corylus decline and concurrent Carpinus expansion at $460 \mathrm{BC}$ were initiated mainly by human impact. In each case, the vegetation shifts were caused not by the arrival of a new "invader" but because of a new augmentation of an already long-present subordinate tree species population, which expanded at the expense of the so-far dominating species, triggered by a change in the factors balancing the then current inter-species competition. Carpinus and Fagus persisted in a small admixture before their major expansions, for no fewer than 1,500 and 2,500 years, respectively. These results are in line with the recently discussed issue of the important role of episodic events in long-term temperate forest ecosystem development and its past dynamics (Bradshaw and Sykes 2014).
Acknowledgments We would like to thank our former masters students, Monika Rode and Katarzyna Jankowska, for their skilful work on macrofossils in the selected sections of the G/I and G/II profiles, respectively. The two anonymous referees are thanked for valuable comments. This study was financed from the project of the Ministry of Science and Higher Education in Poland (MNiSW 3P04F 08723 ) and then continued through statutory funding in the Faculty of Biology, University of Gdańsk (DS/530-L145-D246-13/14).

Open Access This article is distributed under the terms of the Creative Commons Attribution 4.0 International License (http://crea tivecommons.org/licenses/by/4.0/), which permits unrestricted use, distribution, and reproduction in any medium, provided you give appropriate credit to the original author(s) and the source, provide a link to the Creative Commons license, and indicate if changes were made.

\section{References}

Aaby B (1983) Forest development, soil genesis and human activity illustrated by pollen and hypha analysis of two neighbouring podzols in Draved Forest, Denmark. Danmarks Geologiske Undersøgelse II Række 114. Reitzels, København

Aaby B, Berglund BE (1986) Characterization of lake and peat deposits. In: Berglund BE (ed) Handbook of Holocene palaeoecology and palaeohydrology. Wiley, Chichester, pp 231-246

Agestam E, Ekö P-M, Nilsson U, Welander NT (2003) The effects of shelterwood density and site preparation on natural regeneration of Fagus sylvatica in southern Sweden. Forest Ecol Manag 176:61-73

Andersen ST (1984) Forests at Løvenholm, Djursland, Denmark, at present and in the past. Biol Skrift 24:1-208

Andersen ST (1988) Changes in agricultural practices in the Holocene indicated in a pollen diagram from a small hollow in Denmark. In: Birks HH, Birks HJB, Kaland PE, Moe D (eds) The cultural landscape: past present and future. Cambridge University Press, Cambridge, pp 395-407

Austad I (1988) Tree pollarding in western Norway. In: Birks HH, Birks HJB, Kaland PE, Moe D (eds) The cultural landscape: past present and future. Cambridge University Press, Cambridge, pp 11-29

Beug H-J (2004) Leitfaden der Pollenbestimmung für Mitteleuropa und angrenzende Gebiete. Friedrich Pfeil, München

Birks HJB (1986) Late-Quaternary biotic changes in terrestrial and lacustrine envronments, with particular reference to north-west Europe. In: Berglund BE (ed) Handbook of Holocene palaeoecology and palaeohydrology. Wiley, Chichester, pp 3-65

Björkman L (1997) The role of human disturbance in the local Late Holocene establishment of Fagus and Picea forests at Flahult, western Småland, southern Sweden. Veget Hist Archaeobot 6:79-90

Bond G, Showers W, Cheseby M, Lotti R, Almasi P, deMenocal P, Priore P, Cullen H, Hajdas I, Bonani G (1997) A pervasive millennial-scale cycle in North Atlantic Holocene and glacial climates. Science 278:1,257-1,266

Bradshaw RHW (2007) Stand-scale palynology. In: Elias SA (ed) Encyclopedia of quaternary science 3. Elsevier, Amsterdam, pp 2,535-2,543

Bradshaw RHW (2008) Detecting human impact in the pollen record using data-model comparison. Veget Hist Archaeobot 17:597-603 
Bradshaw RHW, Lindbladh M (2005) Regional spread and standscale establishment of Fagus sylvatica and Picea abies in Scandinavia. Ecology 86:1,679-1,686

Bradshaw RHW, Sykes MT (2014) Ecosystem dynamics: from the past to the future. Wiley-Blackwell, Chichester

Bradshaw RHW, Kito N, Giesecke T (2010) Factors influencing the Holocene history of Fagus. Forest Ecol Manag 259:2,204-2,212

Bronk Ramsey C, Lee S (2013) Recent and planned developments of the program OxCal. Radiocarbon 55:720-730

Büntgen U, Tegel W, Nicolussi K, McCormick M et al (2011) 2,500 Years of European climate variability and human susceptibility. Science 331:578-582

Charman DJ, Blundell A, Chiverrell RC, Hendon D, Langdon PG (2006) Compilation of non-annually resolved Holocene proxy climate records: stacked Holocene peatland palaeo-water table reconstructions from northern Britain. Quat Sci Rev 25:336-350

Ellenberg H, Weber HE, Düll R, Wirth V, Werner W, Paulissen D (1988) Zeigerwerte von Pflanzen in Mitteleuropa. Scripta Geobotanica 18. Goltze, Göttingen

Esper J, Frank DC, Timonen M, Zorita E et al (2012) Orbital forcing of tree-ring data. Nat Climate Change. doi:10.1038/ NCLIMATE1589

Fægri K, Iversen J (1989) In: Fægri K. Kaland PE, Krzywinski K (eds) Textbook of pollen analysis. Wiley, Chichester, 4 th edn

Gałka M, Miotk-Szpiganowicz G, Goslar T, Jęśko M, van der Knaap WO, Lamentowicz M (2013) Palaeohydrology, fires and vegetation succession in the southern Baltic during the last 7,500 years reconstructed from a raised bog based on multiproxy data. Palaeogeogr Palaeoclimatol Palaeoecol 370:209-221

Giesecke T, Hickler T, Kunkel T, Sykes MT, Bradshaw RHW (2007) Towards an understanding of the Holocene distribution of Fagus sylvatica L. J Biogeogr 34:118-131

Giesecke T, Bennet KD, Birks HJB, Bjune AE et al (2011) The pace of Holocene vegetation change- testing for synchronous development. Quat Sci Rev 30:2,805-2,814

Grant MJ, Waller MP, Groves JA (2011) The Tilia decline: vegetation change in lowland Britain during the mid and late Holocene. Quat Sci Rev 30:394-408

Haeggström C-A (1990) The influence of sheep and cattle grazing on wooded meadows in Åland, SW Finland. Acta Bot Fen 141:1-28

Hammarlund D, Björck S, Buchardt B, Israelson C, Thomsen CT (2003) Rapid hydrological changes during the Holocene revealed by stable isotope records of lacustrine carbonates from Lake Igelsjön, southern Sweden. Quat Sci Rev 22:353-370

Hejcmanová P, Stejskalová M, Hejcman M (2014) Forage quality of leaf-fodder from the main broad-leaved woody species and its possible consequences for the Holocene development of forest vegetation in Central Europe. Veget Hist Archaeobot 23:607-613

Herbich J (2000) Plant cover of contemporary Gdańsk. Peribalticum 8. GTN, Gdańsk, pp 55-68

Holzhauser H, Magny M, Heinz J, Zumbühl HJ (2005) Glacier and lake-level variations in west-central Europe over the last 3500 years. Holocene 15:789-801

Iversen J (1964) Retrogressive vegetational succession in the postglacial. J Ecol 52(Suppl):59-70

Iversen J (1969) Retrogressive development of a forest ecosystem demonstrated by pollen diagram from fossil mor. Oikos Suppl 12:35-49

Jessen CA, Rundgren M, Björk S, Hammarlund D (2005) Abrupt climatic changes and unstable transition into a late Holocene thermal decline: a multiproxy lacustrine record from southern Sweden. J Quat Sci 20:349-362

Kościński B, Paner H (2005) Nowe wyniki datowania grodu gdańskiego—stanowisko I (wyk. I-IV). In: Paner H, Fudziński
M (eds) XIII Sesja Pomorzoznawcza 2. Muzeum Archeologiczne w Gdańsku, Gdańsk, pp 11-43 (in Polish)

Kuijper DPJ, Cromsigt JPGM, Jędrzejewska B, Miścicki S et al (2010) Bottom-up versus top-down control of tree regeneration in Białowieża Primeval Forest, Poland. J Ecol 98:888-899

Küster H-J (1997) The role of farming in the postglacial expansion of beech and hornbeam in the oakwoodlands of central Europe. Holocene 7:339-342

Lamentowicz M, Jęśko M, Miotk-Szpiganowicz G, Goslar T (2010) Palaeohydrology of Stążki Baltic bog (Kaszuby Lakeland) in period $5300 \mathrm{BC}-950 \mathrm{AD}-$ peatland development and climatic change. Studia Limnol Telmat 4:13-27 (in Polish with English summary)

Latałowa M (1992) Man and vegetation in the pollen diagrams from Wolin Island (NW Poland). Acta Palaeobot 32:123-249

Latałowa M (1995) An outline of the problems of the Holocene palynostratigraphy of the Baltic coastal zone (N Poland). Geol Geomorfol Pobrzeża Południowego Bałtyku 2:111-125 (in Polish with English summary)

Latałowa M, Pędziszewska A, Maciejewska E, Święta-Musznicka J (2013) Tilia forest dynamics, Kretzschmaria deusta attack, and mire hydrology as palaeoecological proxies for mid-Holocene climate reconstruction in the Kashubian Lake District (N Poland). Holocene 23:667-677

Lieschke H, Lotter AF, Fischlin A (2002) Untangling a Holocene pollen record with forest model simulations and independent climate data. Ecol Model 150:1-21

Lindbladh M, Foster DR (2010) Dynamics of long-lived foundation species: the history of Quercus in southern Scandinavia. J Ecol 98:1,330-1,345

Magny M (2004) Holocene climate variability as reflected by midEuropean lake-level fluctuations and its probable impact on prehistoric human settlements. Quat Int 113:65-79

Magny M, Haas JN (2004) A major widespread climatic change around $5300 \mathrm{cal}$ year BP at the time of the Alpine Iceman. J Quat Sci 19:423-430

Magri D, Vendramin GG, Comps B, Dupanloup I et al (2006) A new scenario for the Quaternary history of European beech populations: palaeobotanical evidence and genetic consequences. New Phytol 171:199-221

McCormic M, Büngten U, Cane MA, Cook ER et al (2012) Climate change during and after the Roman empire: reconstructing the past from scientific and historical evidence. J Interdisc Hist 43:169-220

Moore PD, Webb JA, Collinson ME (1991) Pollen analysis, 2nd edn. Blackwell, Oxford

Overballe-Petersen MV, Nielsen AB, Hannon GE, Halsall K, Bradshaw RHW (2013) Long-term forest dynamics at Gribskov, eastern Denmark with early-Holocene evidence for thermophilous broadleaved tree species. Holocene 23:243-254

Owczarek M, Jakusik E, Wojtkiewicz A, Malik P (2007) Climate of Gdańsk, 1981-2005. In: Miętus M, Filipiak J, Wyszkowski A (eds) 200 years of regular meteorological observations and measurements in Gdańsk. Monografie. IMGW, Warszawa, pp 160-183

Pędziszewska A, Tylmann W, Witak M, Piotrowska N, Maciejewska E, Latałowa M (2015) Holocene environmental changes reflected by pollen, diatoms, and geochemistry of annually laminated sediments of Lake Suminko in the Kashubian Lake District (N Poland). Rev Palaeobot Palynol 216:55-75

Punt W et al (eds) (1976-2003) The Northwest European Pollen Flora, I-VIII. Elsevier, Amsterdam

Rackham O (1980) Ancient woodland: its history, vegetation and uses in England. Arnold, London

Ralska-Jasiewiczowa M, Nalepka D, Goslar T (2003) Some problems of forest transformation at the transition to the oligocratic Homo 
sapiens phase of the Holocene interglacial in northern lowlands of central Europe. Veget Hist Archaeobot 12:233-248

Regnell M (2012) Plant subsistence and environment at the Mesolithic site Tågerup, southern Sweden: new insight on the "Nut Age". Veget Hist Archeobot 21:1-16

Reille M (1992-1998) Pollen et Spores d'Europe et d'Afrique du Nord. Laboratoire de Botanique et Palynologie, Marseille

Reimer PJ, Bard E, Bayliss A, Beck JW et al (2013) Selection and treatment of data for radiocarbon calibration: an update to the International Calibration (INTCAL) Criteria. Radiocarbon 55:1-23

Reitalau T, Seppä H, Sugita S, Kangur M et al (2013) Long-term drivers of forest composition in a boreonemoral region: the relative importance of climate and human impact. J Biogeogr 40:1,524-1,534

Rösch M, Kleinmann A, Lechterbeck J, Wick L (2014) Botanical offsite and on-site data as indicators of different land use systems: a discussion with examples from Southwest Germany. Veget Hist Archaeobot 23:S121-S133
Steinhilber F, Beer J (2011) Solar activity-the past 1200 years. PAGES News 19:5-6

Stockmarr J (1971) Tablets with spores used in absolute pollen analysis. Pollen Spores 13:615-621

Szymańska A (1982) Dokumentacja opisowa obszaru AZP 10/43. Archiwum Muzeum Archeologicznego w Gdańsku, Gdańsk (in Polish)

Van der Werf S (1991) The influence of coppicing on vegetation. Vegetatio 92:97-110

Van Geel B (2001) Non-pollen palynomorphs. In: Smol JP, Birks HJB, Last WM (eds) Tracking environmental change using lake sediments 3: terrestrial, algal, and siliceous indicators. Kluwer Academic Publishers, Dordrecht, pp 99-120

Waller M, Grant MJ, Bunting MJ (2012) Modern pollen studies from coppiced woodlands and their implications for the detection of woodland management in Holocene pollen records. Rev Palaeobot Palynol 187:11-28 